\title{
SPATIAL DISTRIBUTION OF JUVENILE FISH SPECIES IN NURSERY GROUNDS OF A TROPICAL COASTAL AREA OF THE SOUTH-WESTERN ATLANTIC
}

\author{
Victor E. L. DA SILVA ${ }^{1 *}$, Elizabeth C. TEIXEIRA ${ }^{2}$, Vandick S. BATISTA ${ }^{2}$, and Nidia N. FABRÉ ${ }^{1}$ \\ ${ }^{1}$ Laboratory of Ecology, Fish and Fisheries, Federal University of Alagoas, Maceió, Brazil \\ ${ }^{2}$ Laboratory of Conservation and Management of Fishery Resources, Federal University of Alagoas, Maceió, Brazil
}

Da Silva V.E.L., Teixeira E.C., Batista V.S., Fabré N.N. 2018. Spatial distribution of juvenile fish species in nursery grounds of a tropical coastal area of the south-western Atlantic. Acta Ichthyol. Piscat. 48 (1): 9-18.

Background. Assessing patterns in habitat utilization and changes in the composition of biont assemblages is a key tool for efficient ecosystem conservation planning and management. Nevertheless, habitat use patterns by juvenile fish still need more comprehension. Therefore, the presently reported study investigated relations between the type of nursery ground and the structure of juvenile fish assemblages in a tropical coastal area of the south-western Atlantic.

Materials and methods. From December 2009 to November 2010, we conducted monthly sampling of ichthyofauna in two habitat types (mangrove and sandy beach) used as nursery grounds by juvenile fish of the south-western Atlantic. Species richness and abundance were used to identify spatial and temporal patterns in the distribution of fish assemblages throughout habitats' dynamics.

Results. A total of 845 fishes representing 16 families and 34 species were found during the presently reported study: Albula vulpes (Linnaeus, 1758); Atherinella brasiliensis (Quoy et Gaimard, 1825); Strongylura marina (Walbaum, 1792); Tylosurus acus acus (Lacepède, 1803); Caranx crysos (Mitchill, 1815); Caranx latus Agassiz, 1831; Oligoplites saurus (Bloch et Schneider, 1801); Selene setapinnis (Mitchill, 1815); Selene vomer (Linnaeus, 1758); Centropomus parallelus Poey, 1860; Centropomus undecimalis (Bloch, 1792); Harengula clupeola (Cuvier, 1829); Opisthonema oglinum (Lesueur, 1818); Anchoa tricolor (Spix et Agassiz, 1829); Anchovia clupeoides (Swainson, 1839); Diapterus auratus Ranzani, 1842; Diapterus rhombeus (Cuvier, 1829); Eucinostomus argenteus Baird et Girard, 1855; Eucinostomus gula (Quoy et Gaimard, 1824); Eucinostomus melanopterus (Bleeker, 1863); Bathygobius soporator (Valenciennes, 1837); Conodon nobilis (Linnaeus, 1758); Haemulon plumierii (Lacepède, 1801); Haemulopsis corvinaeformis (Steindachner, 1868); Hemiramphus brasiliensis (Linnaeus, 1758); Lutjanus apodus (Walbaum, 1792); Lutjanus griseus (Linnaeus, 1758); Lutjanus jocu (Bloch et Schneider, 1801); Mugil brevirostris (Ribeiro, 1915); Mugil curema Valenciennes, 1836; Mugil curvidens Valenciennes, 1836; Paralichthys tropicus Ginsburg, 1933; Sphyraena barracuda (Edwards, 1771); Sphoeroides testudineus (Linnaeus, 1758). No significant differences in species richness and total abundance were found between habitats and seasons. Nevertheless, our analyses showed that distinct sets of species use these areas. Moreover, we identified a strong relation between the rainfall and the species turnover in both habitats studied.

Conclusion. Diversity of nursery grounds in coastal areas not only increases fish diversity but also plays an important role in the sustaining fish stocks.

Keywords: fish fauna, habitat heterogeneity, mangrove, nursery grounds, sandy beach

\section{INTRODUCTION}

Coastal and estuarine habitats play an important role in growth, feeding, and protection of many species (Blaber and Blaber 1980, Barletta et al. 2005, Vasconcelos et al. 2010), especially by serving as nursery grounds for juveniles of marine, freshwater, and estuarine-resident and brackish-water fishes (Beck et al. 2003, Elliott et al. 2007). Though frequently credited for sustaining fish stocks (Beck et al. 2003, Crona and Rönnbäck 2007), these ecosystems, in the global scale, have been impacted by intense habitat degradation processes, mostly caused by human activities (Baptista et al. 2015, Freedman et al. 2016). For instance, the transformation of mangrove areas into shrimp farms along with the shrinking of seagrass coverage due to water quality degradation and increasing beach pollution in tropical regions have been vastly associated with losses of fish diversity and remarkable declines in fishery catches (Arthington et al. 2016). As a 
result, natural and anthropogenic impacts on coastal biota have been constantly assessed by ecologists, but some processes still demand more comprehension, such as the reciprocal relations between the species and the local conditions.

Furthermore, our poor understanding of habitat use patterns by juvenile fish makes conservation planning in coastal areas a really challenging task (Barletta et al. 2010). This particular problem can be blamed on numerous studies that treated these areas as a homogeneous environment, disregarding their diversity reflected by different habitat types, such as, mangroves, seagrass beds, sandy beaches, and mudflats (Nagelkerken et al. 2000a, Beck et al. 2003, Minello et al. 2003). Moreover, many field studies in these ecosystems are often carried out in single habitats, because responsible researchers are often discouraged by their structural complexity, making comparisons of fauna composition difficult (Nagelkerken et al. 2000a). This further translates into a lack of reliable information on the ecosystem as a whole. Mangroves, for instance, have traditionally received considerable attention from scientific community due to their distinct features, such as high structural complexity and greater food abundance (Vendel and Chaves 2006, Vilar et al. 2011, CastellanosGalindo and Krumme 2014). Consequently, other habitats, especially those without vegetation coverage, such as coastal sandy beaches, have been less-intensively investigated (Santos and Nash 1995, Barletta et al. 2010, Rodrigues and Vieira 2013, Lacerda et al. 2014, Blaber and Barletta 2016).

Since different coastal habitats have distinct features (e.g., structural complexity) and dynamics, it is likely that they may vary in their ecological functions as nursery grounds (Beck et al. 2003). Thus, identifying patterns in habitat utilization and changes in the composition of assemblages is extremely necessary for proper conservation planning and management of fishery resources in these environments (Barletta et al. 2010, Blaber and Barletta 2016). In this respect, our study intended to assess patterns in the distribution of juvenile fish assemblages in a coastal area from the south-western Atlantic, considering its availability of nursery grounds and possible relations between species and environmental conditions. Specifically, we used species richness and fish abundance to answer the following questions:

Is the structuring of juvenile fish assemblages in these areas associated with the different types of habitats used as nursery grounds?

Which (and how) environmental conditions affect the spatial distribution of juveniles in these habitats?

\section{MATERIALS AND METHODS}

Study area and fish sampling. The study was carried out in the Santo Antônio River estuary $\left(9^{\circ} 24^{\prime} 50^{\prime \prime} \mathrm{S}, 35^{\circ} 30^{\prime} 24^{\prime \prime} \mathrm{W}\right)$, located on the north-eastern coast of Brazil, South America (Fig. 1). The fishes were sampled monthly using a monofilament beach seine (15 m wide, $2 \mathrm{~m}$ high, and 5-mm mesh size) from December 2009 through November 2010 at four sites located in two different habitat types.
Two sites were situated on the left bank of the estuary, covered with mangrove forest dominated by Rhizophora mangle, Avicennia schaueriana, and Laguncularia racemosa, whereas the other two sites were located in the shallow waters of a sandy beach (mean depth $\leq 1.5$ $\mathrm{m})$ adjacent to the estuary mouth. Each site was sampled once per month (a total of 48 samples) for 5 min and only one net type was used to minimize impacts on the existent fauna. Upon capture, all fishes collected were kept on ice. In the laboratory, each individual was identified to species level following regional taxonomic keys (Figueiredo and Menezes 1978, 1980, Menezes and Figueiredo 1980, 1985).

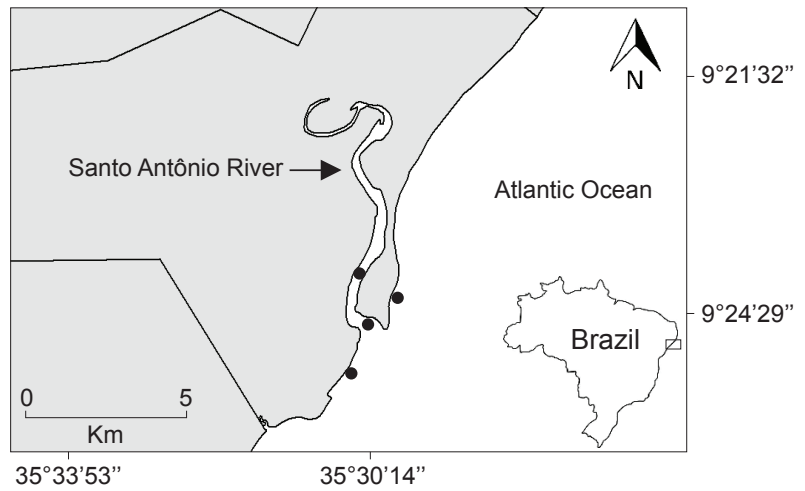

Fig. 1. The Santo Antônio River estuary located on the north-eastern coast of Brazil, indicating the location of sampling sites $(\bullet$

During fieldwork, water physicochemical parameters, such as salinity [\%o], temperature $\left[{ }^{\circ} \mathrm{C}\right]$, and dissolved oxygen [\%] were also measured at each site before fish sampling using a Hanna HI 9828 multi-parameter water quality portable meter. Monthly rainfall data [mm] were obtained from the National Institute of Meteorology (INMET), and these data were used to identify seasonal trends. The rainy season was defined as the period from March through August (monthly rainfall 205.4 \pm 133.4 $\mathrm{mm}$ ) and the dry season from September through February $(64.5 \pm 63.8 \mathrm{~mm})$.

Data analysis. Non-parametric Kruskal-Wallis test was used to identify spatial and seasonal patterns in environmental conditions for both habitats since data did not meet the assumptions of normality and homoscedasticity even after transformations. Variations in species richness and total fish abundance were tested between the mangrove and sandy beach sites, and over time (dry and rainy reason) using two-way analysis of variance (ANOVA). Prior to analysis, data were log-transformed $\left(\ln _{n+1}\right)$ to reduce the effect of data aggregation. Normality and homogeneity of datasets were then tested by Shapiro-Wilk and Levene's tests, respectively.

Differences in the composition of fish assemblages among habitats and seasons were assessed by two-way analysis of similarity (ANOSIM) using the Bray-Curtis similarity coefficient (Clarke 1993). To further identify patterns in assemblages, we also performed a non-metric 
multidimensional scaling (nMDS) (Anderson and Walsh 2013). Subsequently, species which contributed the most to the total dissimilarity between samples were identified using a similarity percentage analysis (SIMPER).

Furthermore, interactions between species abundance and environmental conditions were investigated by canonical correspondence analysis (CCA). CCA was chosen after we tested the gradient length of species composition by detrended correspondence analysis (DCA) as suggested by ter Braak (1995). Environmental variables were previously tested for collinearity by Pearson's correlations with a threshold of 0.7 (Dormann et al. 2012). The two firsts components' scores and factor loadings of CCA were then plotted to detect general gradients in ecological and environmental descriptors. Additionally, the Monte-Carlo permutation test was used to determine if the correlations found between species and environmental conditions were statically significant. All analyses were performed in the software R statistics with the package 'Vegan' (Oksanen 2016) at a significance level of $P<0.05$.

The presently reported study has been carried out in accordance with Brazilian regulations (Federal Scientific Fish Sampling Licence 1837810).

\section{RESULTS}

The annual precipitation reached $1610 \mathrm{~mm}$ and approximately $76 \%$ of this total fell during the rainy season (March through August). Water temperature and dissolved oxygen did not differ between habitats and seasons $(P>0.05)$. Salinity was higher and stable during the entire year in the sandy beach $(P>0.05)$, whereas in the mangrove a seasonal trend could be observed $(P<0.05)$.
This trend was characterized by the decreasing of salinity at the end of the dry season, reaching the lowest values during the months with high rainfall rates (Fig. 2).

A total of 845 fishes representing 16 families and 34 species were collected during the study period: Albula vulpes (Linnaeus, 1758); Atherinella brasiliensis (Quoy et Gaimard, 1825); Strongylura marina (Walbaum, 1792); Tylosurus acus acus (Lacepède, 1803); Caranx crysos (Mitchill, 1815); Caranx latus Agassiz, 1831; Oligoplites saurus (Bloch et Schneider, 1801); Selene setapinnis (Mitchill, 1815); Selene vomer (Linnaeus, 1758); Centropomus parallelus Poey, 1860; Centropomus undecimalis (Bloch, 1792); Harengula clupeola (Cuvier, 1829); Opisthonema oglinum (Lesueur, 1818); Anchoa tricolor (Spix et Agassiz, 1829); Anchovia clupeoides (Swainson, 1839); Diapterus auratus Ranzani, 1842; Diapterus rhombeus (Cuvier, 1829); Eucinostomus argenteus Baird et Girard, 1855; Eucinostomus gula (Quoy et Gaimard, 1824); Eucinostomus melanopterus (Bleeker, 1863); Bathygobius soporator (Valenciennes, 1837); Conodon nobilis (Linnaeus, 1758); Haemulon plumierii (Lacepède, 1801); Haemulopsis corvinaeformis (Steindachner, 1868); Hemiramphus brasiliensis (Linnaeus, 1758); Lutjanus apodus (Walbaum, 1792); Lutjanus griseus (Linnaeus, 1758); Lutjanus jocu (Bloch et Schneider, 1801); Mugil brevirostris (Ribeiro, 1915); Mugil curema Valenciennes, 1836; Mugil curvidens Valenciennes, 1836; Paralichthys tropicus Ginsburg, 1933; Sphyraena barracuda (Edwards, 1771); Sphoeroides testudineus (Linnaeus, 1758) (Table 1). Fish assemblages were mainly comprised of juveniles (73\% of total abundance). In terms of number of individuals, the most abundant species in the mangrove were Atherinella
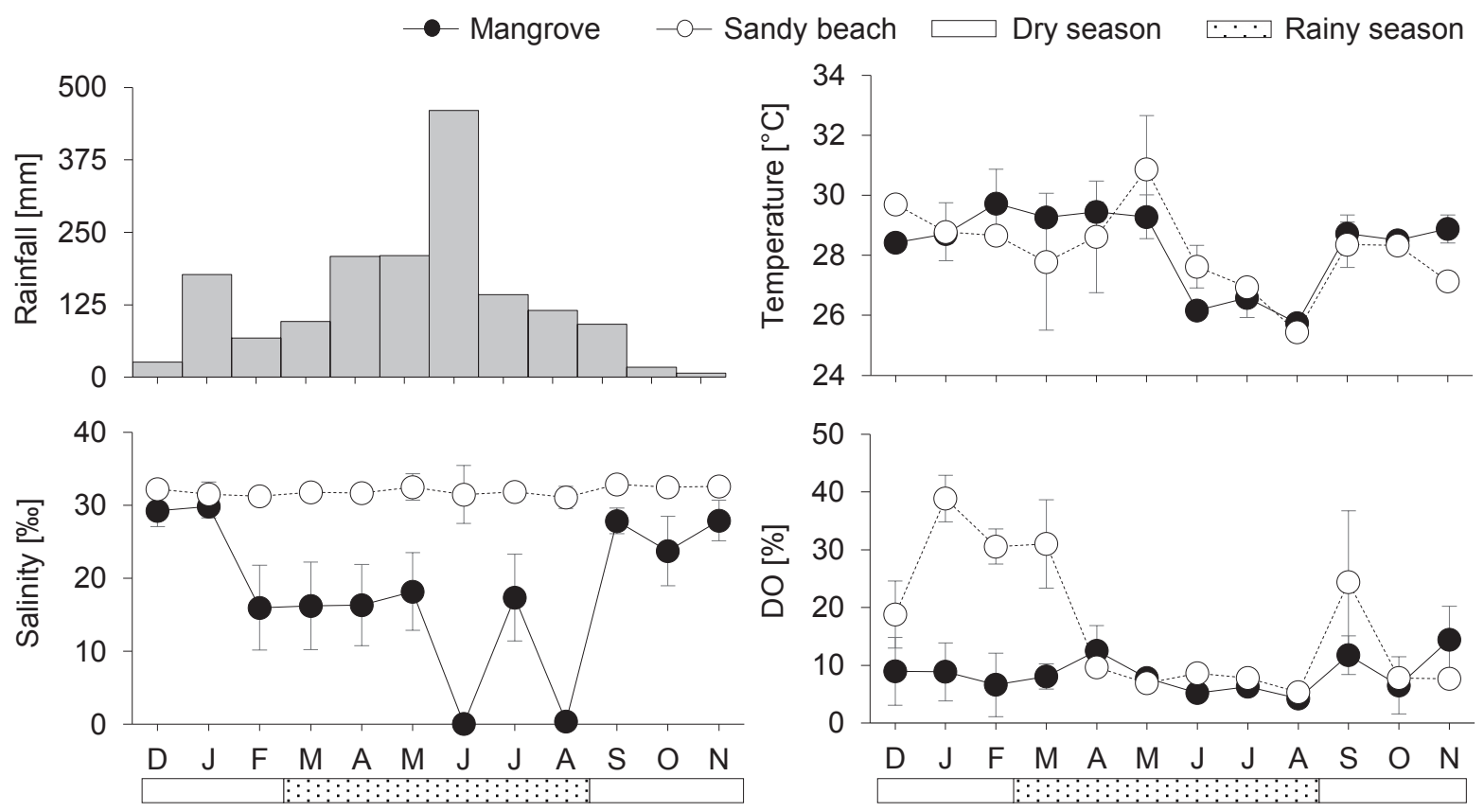

Months

Fig. 2. Rainfall, mean water temperature, salinity, and dissolved oxygen registered in the mangrove and the sandy beach studied at the Santo Antônio River estuary during December 2009 and November 2010 
brasiliensis (20.5\%), Mugil curema (17.8\%), Caranx latus (12.2\%), Diapterus rhombeus (Cuvier, 1829) (10.5\%), Eucinostomus melanopterus (9.9\%), and Anchovia clupeoides $(9.2 \%)$, whereas in the sandy beach the most important species in number, besides A. brasiliensis (20.9\%), C. latus (17.9\%), and M. curema (13.5\%), were Mugil curvidens (9.5\%), Haemulopsis corvinaeformis (9.2\%), and Hemiramphus brasiliensis (8\%). Fourteen of these species were exclusively found in mangrove sites, while nine occurred only in the sandy beach area. The eleven species that occurred in both habitats accounted for $70 \%$ of total abundance. Even though higher species richness and abundance were registered in some samples from mangrove than from sandy beach (Fig. 3), no significant differences between habitats and among seasons were found (ANOVA, $P>0.05$ ), neither an interaction between these two factors could be observed (ANOVA, $P>0.05$, see Table 2 for the total ANOVA output).

While no significant differences in the structure of assemblages between seasons were found (ANOSIM, $R=$ $0.16, P>0.05)$, fish composition varied significantly between mangrove and sandy beach sites (ANOSIM, $R=0.1982$, $P<0.05$ ) (Fig. 4). According to SIMPER analysis, these differences were partly due to fluctuations in the abundance of common species to both habitats (e.g., Atherinella brasiliensis and Mugil curema), as well as the exclusive occurrence of a few species in only one habitat, such as
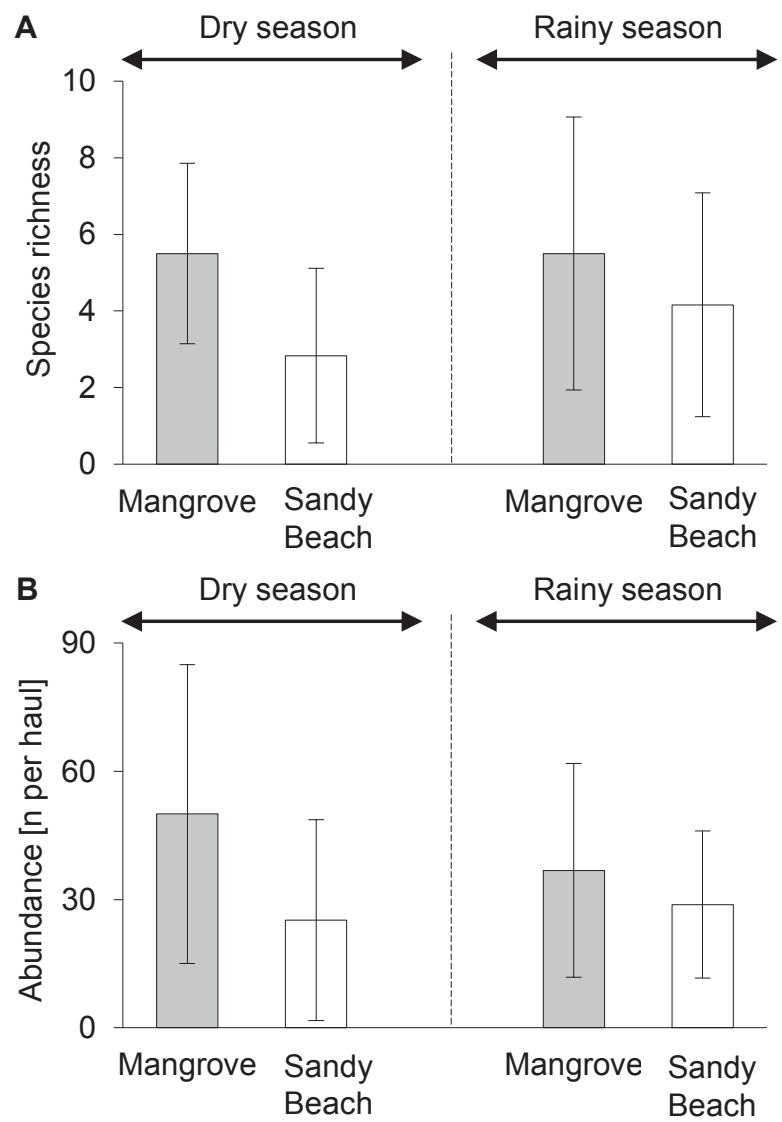

Fig. 3. Variation (mean $\pm \mathrm{SD}$ ) in the species richness (A) and total fish abundance (B) among habitats and seasons in the Santo Antônio River estuary
Diapterus rhombeus in the mangrove and Haemulopsis corvinaeformis in the sandy beach (Table 3, Fig. 5).

Though some environmental conditions showed a certain degree of correlation (Table 4), none of them presented collinearity $(R>0.7)$, therefore CCA was performed including all four studied variables. The two first axes of CCA explained $65 \%$ of total variation in the relation between species and environmental conditions. Considering their vectors length and the Monte Carlo permutation test, rainfall was found to be the most significant factor influencing the distribution and abundance of most species (Fig. 6, $P<0.05$ ).

\section{DISCUSSION}

Many factors can be associated with temporal and spatial changes in species composition of coastal environments, such as substrate type (Nagelkerken et al. 2000b), fluctuations in environmental conditionsespecially, salinity, temperature and dissolved oxygen(Harrison and Whitfield 2006, Ooi and Chong 2011), and inter- and intraspecific relations (Elliott et al. 2007). However, habitat utilization patterns in nursery grounds are still partly unclear. For example, although mangrove vegetation coverage is often related to the sustaining of future fish populations, providing food and shelter availability for juveniles (Nagelkerken et al. 2001, Beck et al. 2003, Sales et al. 2016), the absence of significant differences in species richness and total fish abundance reported in our study and in some other earlier works (Blaber et al. 1989, Sichum and Tantichodok 2013) shows that non-vegetated areas, such as sandy beaches, are also suitable environments for several species.

Differences in the composition of juvenile fish assemblages from mangrove and sandy beach found in our data indicate that different sets of species use these areas as nursery grounds. Such variability may result from specialization in habitat exploitation by species and by habitat dynamics (Igulu et al. 2014, Ebner et al. 2016). The ability to use different environments within single ecosystems may depend on species trophic level, morphological characteristics, and functional attributes (Matthews et al. 2010, Mouillot et al. 2013, de Andrade et al. 2015). For instance, fish which inhabit a greater variety of habitats typically present distinct physiologic adaptations, intraspecific variability in fish behaviour (Bourke et al. 1997, Silva-Falcão et al. 2012) and greater functional specialization and originality (Sales et al. 2016). Our results support this information as species which were common to both habitats (e.g., Atherinella brasiliensis and Mugil curema) have been previously reported in literature as presenting high plasticity in their diet (Rueda 2002, Contente et al. 2010) and great tolerance to changes on environmental conditions that are typical of coastal environments (Neves et al. 2006, Albieri et al. 2010).

Fluctuations of the environmental conditions are closely related to the structure of fish assemblages (Blaber et al. 1989, 2010, Harrison and Whitfield 2006) and habitat selection by species (Porter and Church 1987, Bernardo 
et al. 2003). In tropical regions, for instance, variations coincided with remarkable changes in species composition in dissolved oxygen, salinity, and rainfall often affect fish in both habitats. However, it is important to notice that movements and migration, influencing total density and rainfall affected their dynamics in different ways.

biomass (Barletta et al. 2005, Gaonkar et al. 2013, Campbell In the mangrove, the rainfall was negatively correlated and Rice 2014). In our study, rainfall was found to be the with the salinity, creating a seasonal trend in this habitat. main driver of spatial variability among juvenile fish fauna. Many authors have indicated that the salinity was the In general, over the studied period, changes in rainfall rate main factor structuring fish assemblages in coastal areas

Table 1

Total number of individuals $(n)$ and relative abundance in percentage $(\mathrm{Ab} \%)$ of fish species caught in microhabitats of the Santo Antônio River estuary during December 2009 and November 2010

\begin{tabular}{|c|c|c|c|c|c|}
\hline \multirow{2}{*}{ Family } & \multirow{2}{*}{ Species } & \multicolumn{2}{|c|}{ Mangrove } & \multicolumn{2}{|c|}{ Sandy beach } \\
\hline & & $n$ & $\mathrm{Ab} \%$ & $n$ & $\mathrm{Ab} \%$ \\
\hline Albulidae & Albula vulpes & - & - & 14 & 4.32 \\
\hline Atherinopsidae & Atherinella brasiliensis & 105 & 20.5 & 68 & 20.9 \\
\hline \multirow[t]{2}{*}{ Belonidae } & Strongylura marina & 3 & 0.58 & 2 & 0.61 \\
\hline & Tylosurus acus acus & 1 & 0.19 & - & - \\
\hline \multirow[t]{5}{*}{ Carangidae } & Caranx crysos & 5 & 0.98 & 1 & 0.30 \\
\hline & Caranx latus & 63 & 12.3 & 58 & 17.9 \\
\hline & Oligoplites saurus & - & - & 9 & 2.77 \\
\hline & Selene setapinnis & - & - & 1 & 0.30 \\
\hline & Selene vomer & - & - & 1 & 0.30 \\
\hline \multirow[t]{2}{*}{ Centropomidae } & Centropomus parallelus & 14 & 2.74 & - & - \\
\hline & Centropomus undecimalis & 7 & 1.37 & - & - \\
\hline \multirow[t]{2}{*}{ Clupeidae } & Harengula clupeola & - & - & 15 & 4.62 \\
\hline & Opisthonema oglinum & 1 & 0.19 & - & - \\
\hline \multirow[t]{2}{*}{ Engraulidae } & Anchoa tricolor & - & - & 1 & 0.30 \\
\hline & Anchovia clupeoides & 48 & 9.41 & - & - \\
\hline \multirow[t]{5}{*}{ Gerreidae } & Diapterus auratus & 2 & 0.39 & - & - \\
\hline & Diapterus rhombeus & 55 & 10.7 & - & - \\
\hline & Eucinostomus argenteus & 2 & 0.39 & 13 & 4.01 \\
\hline & Eucinostomus gula & 1 & 0.19 & - & - \\
\hline & Eucinostomus melanopterus & 52 & 10.1 & 3 & 0.92 \\
\hline Gobiidae & Bathygobius soporator & 4 & 0.78 & - & - \\
\hline \multirow[t]{3}{*}{ Haemulidae } & Conodon nobilis & - & - & 1 & 0.30 \\
\hline & Haemulon plumierii & 3 & 0.58 & - & - \\
\hline & Haemulopsis corvinaeformis & - & - & 30 & 9.25 \\
\hline Hemiramphidae & Hemiramphus brasiliensis & 5 & 0.98 & 26 & 8.02 \\
\hline \multirow[t]{3}{*}{ Lutjanidae } & Lutjanus apodus & 14 & 2.74 & 1 & 0.30 \\
\hline & Lutjanus griseus & 3 & 0.58 & - & - \\
\hline & Lutjanus jocu & 2 & 0.39 & - & - \\
\hline \multirow[t]{3}{*}{ Mugilidae } & Mugil brevirostris & 1 & 0.19 & - & - \\
\hline & Mugil curema & 93 & 18.2 & 44 & 13.5 \\
\hline & Mugil curvidens & 14 & 2.74 & 31 & 9.56 \\
\hline Paralichthyidae & Paralichthys tropicus & 1 & 0.19 & - & - \\
\hline Sphyraenidae & Sphyraena barracuda & - & - & 1 & 0.30 \\
\hline Tetraodontidae & Sphoeroides testudineus & 11 & 2.15 & 4 & 1.23 \\
\hline
\end{tabular}

Two-way ANOVA results for species richness and total abundance of studied fish assemblages

Table 2

\begin{tabular}{|c|c|c|c|c|c|c|c|c|}
\hline \multirow{2}{*}{ Factor } & \multicolumn{4}{|c|}{ Species richness } & \multicolumn{4}{|c|}{ Total abundance } \\
\hline & Df & MS & $F$ & $P$ & Df & MS & $F$ & $P$ \\
\hline Habitat & 1 & 1.44858 & 2.38 & 0.1386 & 1 & 5.43127 & 2.50 & 0.1284 \\
\hline Season & 1 & 0.05846 & 0.09 & 0.7598 & 1 & 0.93749 & 0.43 & 0.5181 \\
\hline Interaction & 1 & 0.40655 & 0.66 & 0.4234 & 1 & 2.13074 & 0.98 & 0.3331 \\
\hline
\end{tabular}

$\mathrm{Df}=$ degree of freedom, $\mathrm{MS}=$ mean sum of squares, $F=F$-statistic, $P=P$-value. 
(Barletta et al. 2005, Whitfield et al. 2012, Campbell and Rice 2014). Specifically, shifts in the salinity create a stressful environment for different species which are typical of these areas (e.g., marine, freshwater, estuarineresident and brackish-water species), as each group has a distinct osmoregulatory capacity (Whitfield et al. 2012, Telesh et al. 2013), causing species to respond differently

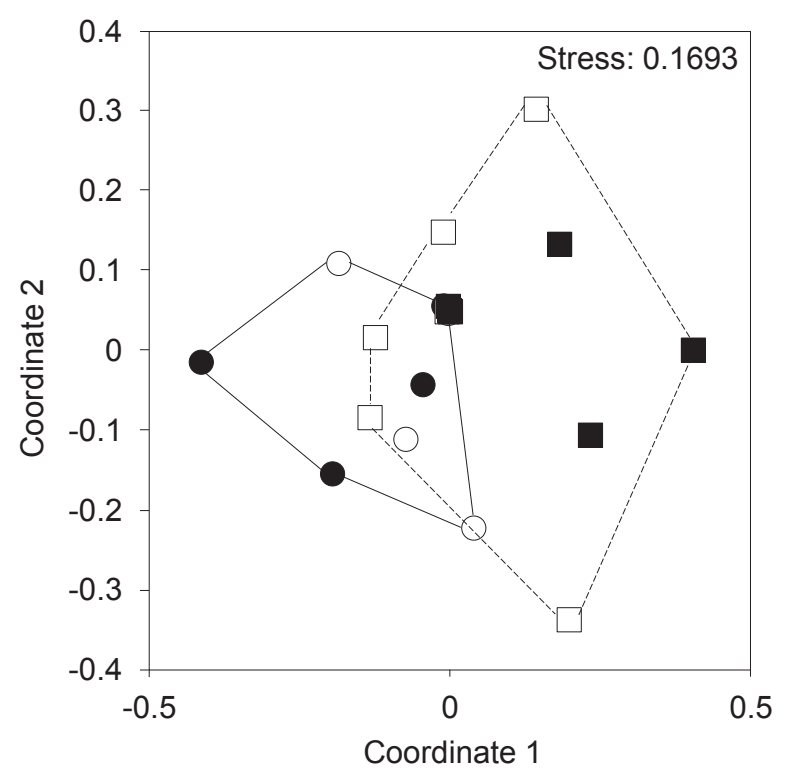

Fig. 4. nMDS ordination of fish abundance per sample among microhabitats in the Santo Antônio River estuary; each point represents a sample: - mangrove (rainy season); $\square$ mangrove (dry season); • sandy beach (rainy season); o sandy beach (dry season) to the salinity gradient. Moreover, the salinity regime promotes changes in organic matter, nutrients, and in dissolved and particulate matter, affecting dissolved oxygen levels (Campbell and Rice 2014) and turbidity (Barletta et al. 2005). These, in turn, may limit the abundance and occurrence of many species (de Jonge and de Jong 2002). On the other hand, since the salinity did not vary in the sandy beach throughout the year, the rainfall appeared to be more associated with the discharge of waters from continental environments, which increases primary and secondary productivity (Oliveira and Kjerfve 1993, Pereira et al. 2015). Besides, wave actions in these environments tend to be stronger during the rainy season, producing a remineralization process of organic matter, which makes a greater quantity of nutrients in water column available, also increasing productivity levels (Rodrigues and Vieira 2013, Lacerda et al. 2014). Greater food availability increases fish diversity and makes the environment more suitable for several species, especially for juveniles which depend on high food availability for growth (Jones 1986).

In conclusion, the results found herein provide some insights about the spatial arrangement of juvenile of fish species in nursery grounds of coastal areas. Our data suggest that the distinct dynamics of habitats located in coastal areas allows different sets of species to inhabit them, not only increasing fish diversity but also playing a key role in the sustaining of fish stocks. Such information is supported by the absence of differences in species richness and total fish abundance in studied fish assemblages, and by the occurrence of distinct species in both habitats. Furthermore, we also highlighted rainfall as the main seasonal factor influencing, directly and indirectly, the spatial structuring of juvenile assemblages

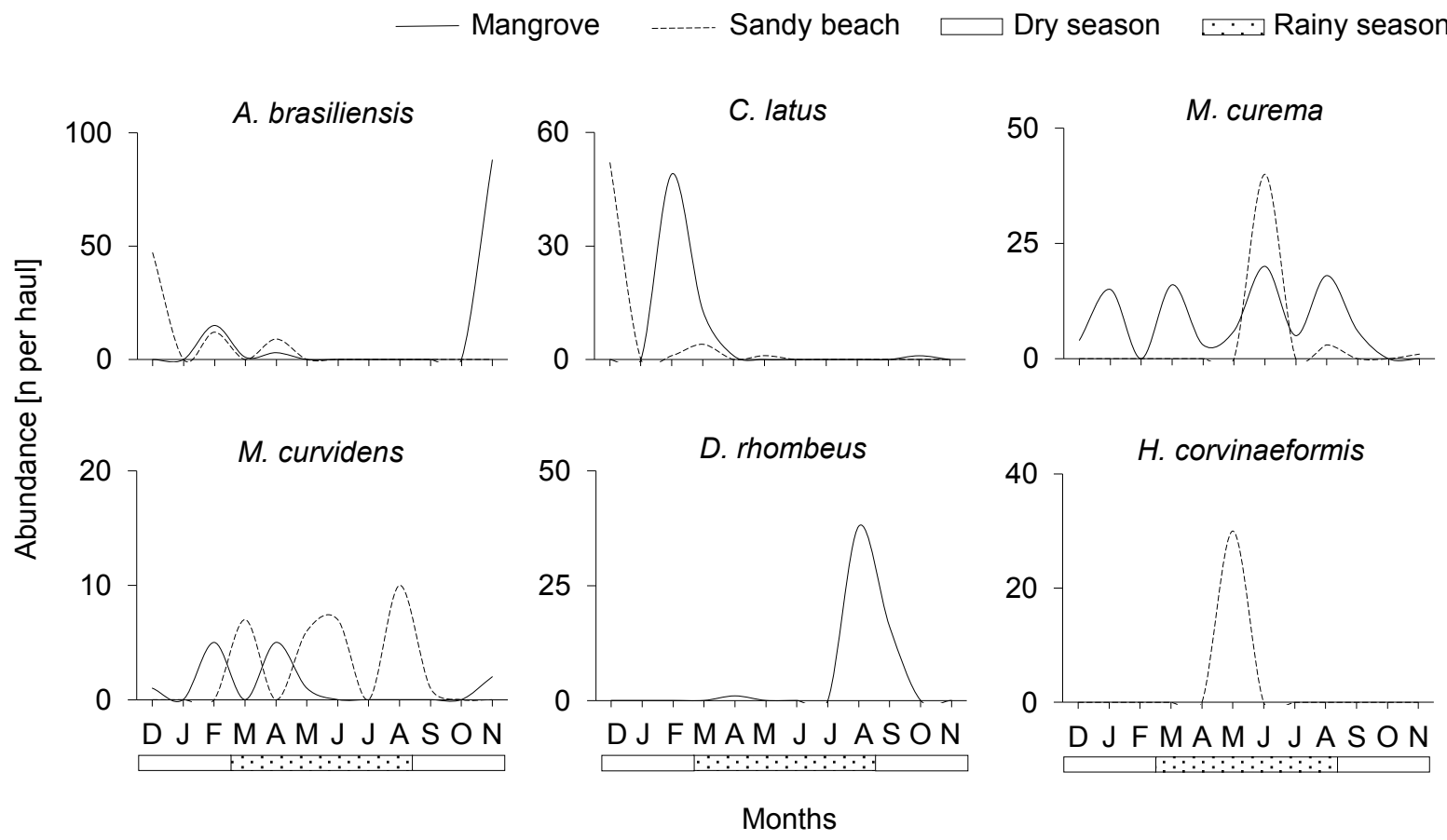

Fig. 5. Fluctuations on the abundance of most common species from the Santo Antônio River estuary 
Table 3

Species identified by SIMPER analysis as responsible for total dissimilarity between assemblages in the mangrove and the sandy beach

\begin{tabular}{lcccc}
\hline \multirow{2}{*}{\multicolumn{1}{c}{ Species }} & \multicolumn{2}{c}{ Dissimilarity } & & \\
\cline { 2 - 4 } & Contribution [\%] & Accumulated [\%] & Mangrove [Ab\%] & Sandy beach [Ab\%] \\
\hline Mugil curema & 19.55 & 19.55 & 15.47 & 8.85 \\
Atherinella brasiliensis & 16.00 & 35.56 & 17.86 & 16.60 \\
Caranx latus & 10.56 & 46.11 & 10.66 & 14.30 \\
Mugil curvidens & 7.58 & 53.70 & 2.33 & 6.25 \\
Eucinostomus melanopterus & 7.23 & 60.94 & 8.67 & 0.65 \\
Hemiramphus brasiliensis & 5.23 & 66.17 & 0.83 & 5.45 \\
Diapterus rhombeus & 4.93 & 71.10 & 9.17 & 0.00 \\
Anchovia clupeoides & 4.89 & 75.99 & 8.00 & 0.00 \\
Haemulopsis corvinaeformis & 3.78 & 79.78 & 0.00 & 6.00 \\
Harengula clupeola & 3.47 & 83.25 & 0.00 & 3.10 \\
Albula vulpes & 3.37 & 86.63 & 0.00 & 3.50 \\
\hline
\end{tabular}

$\mathrm{Ab} \%=$ relative abundance in percent.

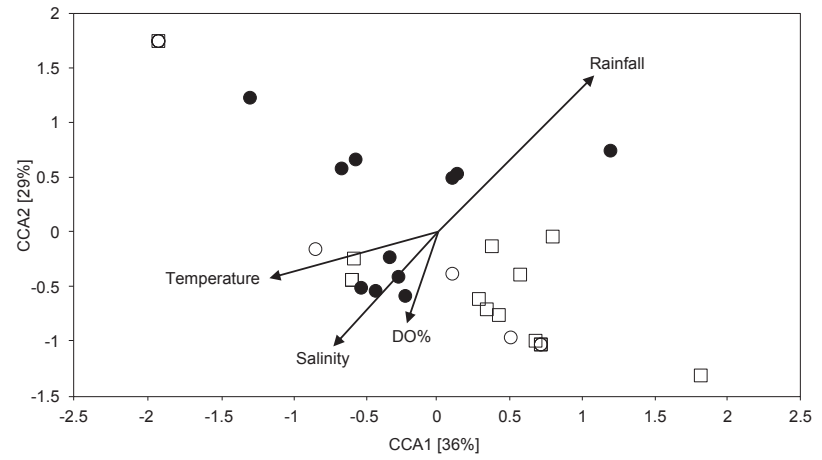

Fig. 6. Canonical correspondence analysis ordination bi-plot based on species found in estuarine habitats (• mangrove; ○ sandy beach; $\square$ both) from the Santo Antônio River in relation to environmental variables (arrows; DO $\%$ = dissolved oxygen)

Table 4

Pearson correlation matrix for the environmental variables measured

\begin{tabular}{lcccc}
\hline & $\begin{array}{c}\text { Dissolved } \\
\text { oxygen } \\
{[\%]}\end{array}$ & $\begin{array}{c}\text { Rainfall } \\
{[\mathrm{mm}]}\end{array}$ & $\begin{array}{c}\text { Salinity } \\
{[\%]}\end{array}$ & $\begin{array}{c}\text { Temperature } \\
{\left[{ }^{\circ} \mathrm{C}\right]}\end{array}$ \\
\hline $\begin{array}{l}\text { Dissolved } \\
\text { oxygen }\end{array}$ & 1.00 & & & \\
Rainfall & -0.23 & 1.00 & & \\
Salinity & 0.51 & -0.61 & 1.00 & \\
Temperature & 0.48 & -0.20 & 0.61 & 1.00 \\
\hline
\end{tabular}

in coastal nursery grounds. However, further investigation on long-term changes in habitats' dynamics is necessary for a better understanding of how this variable affects the fish composition. Our work provides essential data for understanding shifts in the species composition, which are extremely necessary for the development of effective conservation plans for ecosystems as a whole.

\section{ACKNOWLEDGMENTS}

We would like to thank colleagues Any Lopes, Cibele Tiburtino, Jordana Rangely, and Marcia Sousa for their assistance during field and laboratory work. This study was supported by the Brazilian National Council for Scientific and Technological Development - CNPq (V.S.B., grant number 303469/2013-7; N.N.F., grant number 306624/2014-1); and the Coordination for the Improvement of Higher Education Personnel - Capes.

\section{REFERENCES}

Albieri R.J., Araújo F.G., Uehara W. 2010. Differences in reproductive strategies between two co-occurring mullets Mugil curema Valenciennes 1836 and Mugil liza Valenciennes 1836 (Mugilidae) in a tropical bay. Tropical Zoology 23 (1): 51-62.

Anderson M.J., Walsh D.C.I. 2013. PERMANOVA, ANOSIM , and the Mantel test in the face of heterogeneous dispersions: What null hypothesis are you testing? Ecological Monographs 83 (4): 557-574. DOI: 10.1890/12-2010.1

Arthington A.H., Dulvy N.K., Gladstone W., Winfield I.J. 2016. Fish conservation in freshwater and marine realms: Status, threats and management. Aquatic Conservation: Marine and Freshwater Ecosystems 26 (5): 838-857. DOI: 10.1002/aqc.2712

Baptista J., Martinho F., Nyitrai D., Pardal M.A., Dolbeth M. 2015. Long-term functional changes in an estuarine fish assemblage. Marine Pollution Bulletin 97 (1-2): 125-134. DOI: 10.1016/j. marpolbul.2015.06.025

Barletta M., Barletta-Bergan A., Saint-Paul U., Hubold G. 2005. The role of salinity in structuring the fish assemblages in a tropical estuary. Journal of Fish Biology 66 (1): 45-72. DOI: 10.1111/j.00221112.2005.00582.x

Barletta M., Jaureguizar A.J., Baigun C., Fontoura N.F., Agostinho A.A., Almeida-Val V.M.F., Val A.L., Torres R.A., Jimenes-Segura L.F., Giarrizzo 
T., Fabré N.N., Batista V.S., Lasso C., Taphorn D.C., Costa M.F., Chaves P.T., Vieira J.P., Corrêa M.F.M. 2010. Fish and aquatic habitat conservation in South America: A continental overview with emphasis on neotropical systems. Journal of Fish Biology 76 (9): 2118-2176. DOI: 10.1111/j.1095-8649.2010.02684.X

Beck M.W., Heck K.L.jr., Able K.W., Childers D.L., Eggleston D.B., Gillanders B.M., Halpern B.S., Hays C.G., Hoshino K., Minello T.J., Orth R.J., Sheridan P.F., Weinstein M.P. 2003. The role of nearshore ecosystems as fish and shellfish nurseries. Issues in Ecology 2003 (11): 1-12.

Bernardo J.M., Ilhéu M., Matono P., Costa A.M. 2003. Interannual variation of fish assemblage structure in a Mediterranean river: Implications of streamflow on the dominance of native or exotic species. River Research and Applications 19 (5-6): 521-532. DOI: 10.1002/ rra.726

Blaber S.J.M., Barletta M. 2016. A review of estuarine fish research in South America: What has been achieved and what is the future for sustainability and conservation? Journal of Fish Biology 89 (1): 537568. DOI: $10.1111 /$ jfb. 12875

Blaber S.J.M., Blaber T.G. 1980. Factors affecting the distribution of juvenile estuarine and inshore fish. Journal of Fish Biology 17 (2): 143-162. DOI: 10.1111/ j.1095-8649.1980.tb02749.x

Blaber S.J.M., Brewer D.T., Salini J.P. 1989. Species composition and biomasses of fishes in different habitats of a tropical Northern Australian estuary: Their occurrence in the adjoining sea and estuarine dependence. Estuarine, Coastal and Shelf Science 29 (6): 509-531. DOI: 10.1016/0272-7714(89)90008-5

Blaber S.J.M., Griffiths S.P., Pillans R. 2010. Changes in the fish fauna of a tropical Australian estuary since 1990 with reference to prawn predators and environmental change. Estuarine, Coastal and Shelf Science 86 (4): 692-696. DOI: 10.1016/j.ecss.2009.12.012

Bourke P., Magnan P., Rodríguez M.A. 1997. Individual variations in habitat use and morphology in brook charr. Journal of Fish Biology 51 (4): 783-794. DOI: $10.1006 /$ jfbi.1997.0481

Campbell L., Rice J. 2014. Effects of hypoxia-induced habitat compression on growth of juvenile fish in the Neuse River estuary, North Carolina, USA. Marine Ecology Progress Series 497: 199-213. DOI: 10.3354/ meps 10607

Castellanos-Galindo G.A., Krumme U. 2014. Longterm stability of tidal and diel-related patterns in mangrove creek fish assemblages in North Brazil. Estuarine, Coastal and Shelf Science 149: 264-272. DOI: $10.1016 /$ j.ecss.2014.08.016

Clarke K. 1993. Non-parametric multivariate analyses of changes in community structure. Australian Journal of Ecology 18 (1): 117-143. DOI: 10.1111/j.14429993.1993.tb00438.x

Contente R.F., Stefanoni M.F., Spach H.L. 2010. Feeding ecology of the Brazilian silverside Atherinella brasiliensis (Atherinopsidae) in a sub-tropical estuarine ecosystem. Journal of the Marine Biological Association of the United Kingdom 91 (6): $1197-$ 1205. DOI: $10.1017 / \mathrm{S} 0025315410001116$

Crona B.I., Rönnbäck P. 2007. Community structure and temporal variability of juvenile fish assemblages in natural and replanted mangroves, Sonneratia alba Sm., of Gazi Bay, Kenya. Estuarine, Coastal and Shelf Science 74 (1-2): 44-52. DOI: 10.1016/j. ecss.2007.03.023

de Andrade A.C., Santos S.R., Verani J.R., Vianna M. 2015. Guild composition and habitat use by Tetraodontiformes (Teleostei, Acanthopterygii) in a south-western Atlantic tropical estuary. Journal of the Marine Biological Association of the United Kingdom 96 (6): 1251-1264. DOI: 10.1017/ S0025315415001368

de Jonge V.N., de Jong D.J. 2002. Ecological restoration in coastal areas in the Netherlands: Concepts, dilemmas and some examples. Hydrobiologia 478 (1-3): 7-28. DOI: 10.1023/A:1021014310819

Dormann C.F., Elith J., Bacher S., Buchmann C., Carl G., Carré G., Marquéz J.R.G., Gruber B., Lafourcade B., Leitão P.J., Münkemüller T., McClean C., Osborne P.E., Reineking B., Schröder B., Skidmore A.K., Zurell D., Lautenbach S. 2012. Collinearity: A review of methods to deal with it and a simulation study evaluating their performance. Ecography 36 (1): 27-46. DOI: 10.1111/j.16000587.2012.07348.x

Ebner B.C., Fulton C.J., Donaldson J.A., Schaffer J. 2016. Distinct habitat selection by freshwater morays in tropical rainforest streams. Ecology of Freshwater Fish 25 (2): 329-335. DOI: 10.1111/eff.12213

Elliott M., Whitfield A.K., Potter I.K., Blaber S.J.M., Cyrus D.P., Nordlie F.G., Harrison T.D. 2007. The guild approach to categorizing estuarine fish assemblages: A global review. Fish and Fisheries 8 (3): 241-268. DOI: 10.1111/j.1467-2679.2007.00253.x

Figueiredo J.L., Menezes N. 1978. Manual de Peixes Marinhos do Sudeste do Brasil. II. Teleostei (1). [Manual of marine fishes of south-eastern Brazil. II. Teleostei (1).] Museu de Zoologia, Universidade de São Paulo, São Paulo, Brazil. [In Portuguese.]

Figueiredo J.L., Menezes N. 1980. Manual de Peixes Marinhos do Sudeste do Brasil. III. Teleostei (2). [Manual of marine fishes of south-eastern Brazil. III. Teleostei (2).] Museu de Zoologia, Universidade de São Paulo, São Paulo, Brazil. [In Portuguese.]

Freedman R.M., Espasandin C., Holcombe E.F., Whitcraft C.R., Allen B.J., Witting D., Lowe C.G. 2016. Using movements and habitat utilization as a functional metric of restoration for estuarine juvenile fish habitat. Marine and Coastal Fisheries: Dynamics, Management, and Ecosystem Science 8 (1): 361-373. DOI: $10.1080 / 19425120.2016 .1161681$

Gaonkar U.V., Sivadas S.K., Ingole B.S. 2013. Effect of tropical rainfall in structuring the macrobenthic community of Mandovi estuary, west coast of India. Journal of the Marine Biological Association of the 
United Kingdom 93 (7): 1727-1738. DOI: 10.1017/ S002531541300026X

Harrison T.D., Whitfield A.K. 2006. Temperature and salinity as primary determinants influencing the biogeography of fishes in South African estuaries. Estuarine, Coastal and Shelf Science 66 (1-2): 335345. DOI: 10.1016/j.ecss.2005.09.010

Igulu M.M., Nagelkerken I., Dorenbosch M., Grol M.G.G., Harborne A.R., Kimirei I.A., Mumby P.J., Olds A.D., Mgaya Y.D. 2014. Mangrove habitat use by juvenile reef fish: Meta-analysis reveals that tidal regime matters more than biogeographic region. PLoS ONE 9 (12): e114715. DOI: 10.1371/journal. pone. 0114715

Jones G.P. 1986. Food availability affects growth in a coral reef fish. Oecologia 70 (1): 136-139. DOI: 10.1007/ BF00377123

Lacerda C.H.F., Barletta M., Dantas D.V. 2014. Temporal patterns in the intertidal faunal community at the mouth of a tropical estuary. Journal of Fish Biology 85 (5): 1571-1602. DOI: 10.1111/jfb.12518

Matthews B., Marchinko K.B., Bolnick D.I., Mazumder A. 2010. Specialization of trophic position and habitat use by sticklebacks in an adaptive radiation. Ecology 91 (4): 1025-1034. DOI: 10.1890/09-0235.1

Menezes N., Figueiredo J.L. 1980. Manual de Peixes Marinhos do Sudeste do Brasil. IV. Teleostei (3). [Manual of marine fishes of south-eastern Brazil. IV. Teleostei (3).] Museu de Zoologia, Universidade de São Paulo: São Paulo, Brazil. [In Portuguese.]

Menezes N., Figueiredo JL. 1985. Manual de Peixes Marinhos do Sudeste do Brasil. V. Teleostei (4). [Manual of marine fishes of south-eastern Brazil. V. Teleostei (4).] Museu de Zoologia, Universidade de São Paulo: São Paulo, Brazil. [In Portuguese.]

Minello T.J., Able K.W., Weinstein M.P., Hays C.G. 2003. Salt marshes as nurseries for nekton: Testing hypotheses on density, growth and survival through meta-analysis. Marine Ecology Progress Series 246: 39-59. DOI: 10.3354/meps246039

Mouillot D., Graham N.A.J., Villéger S., Mason N.W.H., Bellwood D.R. 2013. A functional approach reveals community responses to disturbances. Trends in Ecology and Evolution 28 (3): 167-177. DOI: $10.1016 /$ j.tree.2012.10.004

Nagelkerken I., Dorenbosch M., Verberk W.C.E.P., Cocheret de la Morinière E., van der Velde G. 2000a. Importance of shallow-water biotopes of a Caribbean bay for juvenile coral reef fishes: Patterns in biotope association, community structure and spatial distribution. Marine Ecology Progress Series 202: 175-192. DOI: 10.3354/meps202175

Nagelkerken I., Kleijnen S., Klop T., van den Brand R.A.C.J., Cocheret de la Morinière E., van der Velde G. 2001. Dependence of Caribbean reef fishes on mangroves and seagrass beds as nursery habitats: A comparison of fish faunas between bays with and without mangroves/seagrass beds. Marine Ecology Progress Series 214: 225-235. DOI: 10.3354/meps214225
Nagelkerken I., van der Velde G., Gorissen M.W., Meijer G.J., Van't Hof T., den Hartog C. 2000b. Importance of mangroves, seagrass beds and the shallow coral reef as a nursery for important coral reef fishes, using a visual census technique. Estuarine, Coastal and Shelf Science 51 (1): 31-44. DOI: 10.1006/ecss.2000.0617

Neves L.M., Pereira H.H., da Costa M.R., Araújo F.G. 2006. Uso do manguezal de Guaratiba, Baía de Sepetiba, Rio de Janeiro, pelo peixe-rei Atherinella brasiliensis (Quoy \& Gaimard) (Atheriniformes, Atherinopsidae). [The use of the Guaratiba magrove, Sepetiba Bay, Rio de Janeiro, by the silverside Atherinella brasiliensis (Quoy \& Gaimard) (Atheriniformes, Atherinopsidae)] Revista Brasileira de Zoologia 23 (2): 421-428. [In Portuguese.] DOI: $10.1590 / \mathrm{S} 0101-81752006000200017$

Oksanen J. 2016. Vegan: an introduction to ordination. https://www.ohio.edu/plantbio/staff/mccarthy/ multivariate/intro-vegan.pdf

Oliveira A.M., Kjerfve B. 1993. Environmental responses of a tropical coastal lagoon system to hydrological variability: Mundaú-Manguaba, Brazil. Estuarine, Coastal and Shelf Science 37 (6): 575-591. DOI: 10.1006/ecss.1993.1074

Ooi A.L., Chong V.C. 2011. Larval fish assemblages in a tropical mangrove estuary and adjacent coastal waters: Offshore-inshore flux of marine and estuarine species. Continental Shelf Research 31 (15): 1599-1610. DOI: $10.1016 /$ j.csr.2011.06.016

Pereira H.H., Neves L.M., da Costa M.R., Araújo F.G. 2015. Fish assemblage structure on sandy beaches with different anthropogenic influences and proximity of spawning grounds. Marine Ecology 36 (1): 16-27. DOI: $10.1111 /$ maec. 12113

Porter W.F., Church K.E. 1987. Effects of environmental pattern on habitat preference. Journal of Wildlife Management 51 (3): 681-685. DOI: 10.2307/3801289

Rodrigues F.L., Vieira J.P. 2013. Surf zone fish abundance and diversity at two sandy beaches separated by long rocky jetties. Journal of the Marine Biological Association of the United Kingdom 93 (4): 867-875. DOI: 10.1017/s0025315412001531

Rueda P.S. 2002. Stomach content analysis of Mugil cephalus and Mugil curema (Mugiliformes: Mugilidae) with emphasis on diatoms in the Tamiahua Lagoon, México. Revista de Biologia Tropical 50 (1): 245-252.

Sales N.S., Dias T.L.P., Baeta A., Pessanha A.L.M. 2016. Dependence of juvenile reef fishes on semi-arid hypersaline estuary microhabitats as nurseries. Journal of Fish Biology 89 (1): 661-679. DOI: 10.1111/ jfb. 13006

Santos R.S., Nash R.D.M. 1995. Seasonal changes in a sandy beach fish assemblage at Porto Pim, Faial, Azores. Estuarine, Coastal and Shelf Science 41 (5): 579-591. DOI: 10.1016/0272-7714(95)90028-4

Sichum S., Tantichodok P. 2013. Diversity and assemblage patterns of juvenile and small sized fishes in the nearshore habitats of the Gulf of Thailand. The Raffles Bulletin of Zoology 61 (2): 795-809. 
Silva-Falcão E.C., Severi W., de Araújo M.E. 2012. Spatial-temporal variation of Achirus larvae (Actinopterygii: Achiridae) in mangrove, beach and reef habitats in north-eastern Brazil. Journal of the Marine Biological Association of the United Kingdom 93 (2): 381-388. DOI: 10.1017/S0025315411001706

Telesh I., Schubert H., Skarlato S. 2013. Life in the salinity gradient: Discovering mechanisms behind a new biodiversity pattern. Estuarine, Coastal and Shelf Science, 135: 317-327. DOI: 10.1016/j. ecss.2013.10.013

ter Braak C.J.F. 1995. Ordination. Pp. 91-173. In: Jongman R.H.G., ter Braak C.J.F., van Tongeren O.F.R. (eds.) Data analysis in community and landscape ecology. Cambridge University Press, New York, NY, USA.

Vasconcelos R.P., Reis-Santos P., Maia A., Fonseca V., França S., Wouters N., Costa M.J., Cabral
H.N. 2010. Nursery use patterns of commercially important marine fish species in estuarine systems along the Portuguese coast. Estuarine, Coastal and Shelf Science 86 (4): 613-624. DOI: 10.1016/j. ecss.2009.11.029

Vendel A.L., Chaves P.D.T. 2006. Use of an estuarine environment (Barra do Saí lagoon, Brazil) as nursery by fish. Revista Brasileira de Zoologia 23 (4): 1117 1122. DOI: $10.1590 / \mathrm{S} 0101-81752006000400020$

Vilar C.C., Spach H.L., Souza-Conceiçao J.M. 2011. Fish assemblage in shallow areas of Baía da Babitonga, southern Brazil: Structure, spatial and temporal patterns. Pan-American Journal of Aquatic Sciences 6 (4): 303-319.

Whitfield A.K., Elliott M., Basset A., Blaber S.J.M., West R.J. 2012. Paradigms in estuarine ecology-A review of the Remane diagram with a suggested revised model for estuaries. Estuarine, Coastal and Shelf Science 97: 78-90. DOI: 10.1016/j.ecss.2011.11.026

Received: 29 August 2017

Accepted: 2 January 2018

Published electronically: 31 March 2018 